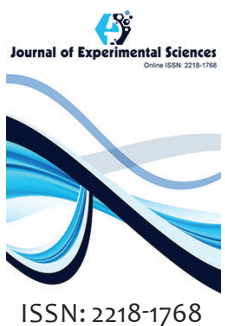

Received: April 21, 2018 Accepted: June 01, 2018 Published: June 09, 2018

*Corresponding Author: Ali Sharief

Email: shariefali42@gmail.com

\section{Leucaena forage yield as influenced by soil conditioner and irrigation regime treatments}

\author{
Ahmed A. Kandil, Ali E. Sharief* \\ Department of Agronomy, Faculty of Agriculture, Mansoura University, Egypt
}

\begin{abstract}
Water is limiting factor of increasing cultivated lands, so water scarcity and drought stress, considered as one of the factors limiting agricultural forage production in the world. This can have achieved by increasing of cultivated pasture area or improving productivity of rangeland plants. Soil conditioners applied in these holes during cultivation and vigorous seedlings transported to this experimental site. Unvarying daily irrigation using a drip irrigation system. Applying poultry manure as soil conditioners in sandy soil twisted tallest shrubs, maximum values of a number of branches/plant, stem thickness and dry matter forage yield per plant and per hectare and uppermost values of water use efficiency at both summer and autumn cuts. Increasing drip irrigation discharges from 2, 4, 6 to 8 litres/h significantly produced the tallest plants, highest number of branches per plant, thickness of stem and dry forage yield/plant and per hectare as well as water use efficiency in both summer and autumn cuts. As regards to the interaction between soil conditioners and drip irrigation discharges on stem height, number of branches/plant, dry forage matter yield per plant and dry forage yield/ha. Applying poultry manure as soil conditioners in sandy soil and increasing discharges of drip irrigation by 8 litres/h significantly increased dry forage yield/ha.
\end{abstract}

KEYWORDS: Soil conditioners in sandy soil, drip irrigation system, Leucaena

\section{INTRODUCTION}

Developing countries of the arid and semi-arid regions, like Egypt, face 4 major obstacles for forage production, namely: high rates of population increase; limited availability of good quality water; existence of salt-affected soils; and competition between uses of resources for producing human food and fodder for livestock. Desertification and salinity are serious problems with crucial impacts on agricultural development, especially in arid and semi-arid zones. Leucaena (Leucaena leucocephala), a very important multi-purpose tree used widely for forage production. These trees enhance fertility of reclaimed soil, help in controlling erosion [1], and could be used for reforestation and refurbishment of besmirched land [2]. Soil conditioners and drip discharge treatments markedly influence growth characteristics of Leucaena leucocephala in silvopastoral [3]. Both poultry and animal (cattle) manures in combination with $6 \mathrm{~L} / \mathrm{h}$ dishrag (drip water at $6 \mathrm{~L} /$ hour) produced excellent growth, while only limited growth occurred in control treatments and those where bitumen was placed inside the walls of the holes when seedlings were planted. Fresh leaves can contain 63\% moisture, which would provide grazing fowls with most of their water requirements. Moreover, most of the dry matter produced by leucaena is in woody stems, which are a valuable source of fuel and hutch timber [4].

Application of organic manures (crop residues, animal manures, green manures) can improve their organic matter content, and can eliminate $\mathrm{Al}$ toxicity and decrease soil acidity. Pulses can fix atmospheric nitrogen via rhizobia [5]. Productivity and chemical composition of leucaena forage is affected by cutting intensity and frequency regime of 70-84 days at $50 \mathrm{~cm}$ stubble height [6]. Cutting frequency and stubble height greatly influence crude protein concentration, with highest values when the herbage is harvested each $42-54$ days at $80 \mathrm{~cm}$ stubble height, in accordance with the recommendations of [7].

Water availability is an important environmental characteristic in arid and semi-arid zones because a general lack of water has a significant impact on agricultural production. Comparatively less investigation has been conducted on leucaena to assess its water use efficiency, especially in arid and semi-arid areas. Application of effective irrigation in arid and semi-arid districts can greatly enhance forage crop yields and increase overall production $[8,9,10]$. The use of soil conditioners in sandy reclaimed soils is very important for seedling establishment, especially in sandy soil. Therefore, we designed this investigation

Copyright: $\odot 2018$ The authors. This article is open access and licensed under the terms of the Creative Commons Attribution License (http://creativecommons.org/licenses/by/4.0/) which permits unrestricted, use, distribution and reproduction in any medium, or format for any purpose, even commercially provided the work is properly cited. Attribution - You must give appropriate credit, provide a link to the license, and indicate if changes were made. 
to investigate the quantity and quality of forage produced by leucaena in newly reclaimed sandy, saline soils and any responses to drip irrigation and application of a range of soil conditioner treatments.

\section{MATERIALS AND METHODS}

\section{Agricultural Practices}

The experimental site is located at the Agriculture Experimental Station at Kalabsho and Zayan, northwest Dakahlia Governorate $\left(931.5^{\circ} \mathrm{N}, 32.31^{\circ} \mathrm{E}\right)$ and $3.5 \mathrm{~km}$ south from the international highway adjacent to the Mediterranean Sea. Annual rainfall is about $120 \mathrm{~mm}(80 \%$ in winter, $10 \%$ in autumn and $10 \%$ in spring). Evaporation rate from a free water surface is about $182 \mathrm{~mm}$ in summer and $69 \mathrm{~mm}$ in winter. Total precipitation during October, November and December 2013 was $80 \mathrm{~mm}$. The soils of the area were salty sands and soil samples from the top 10-15 cm revealed the following attributes: $\mathrm{pH}-8.43$; EC $\mathrm{dS} / \mathrm{m}-8.5$; sand $-88.5 \%$; and organic matter - $0.62 \%$.

The experimental design included 4 cutting times (dates of each cutting), i.e. 17, 20, 23 and 26 months after planting. Regular daily irrigation was applied using a drip irrigation system (for each 4 days), while irrigation water had salinity level of $1500 \mathrm{mhos} / \mathrm{cm}$. Valves and a calibrated pressure gauge were fixed at each lateral inlet to control irrigation time under the nominal operating pressure of 1 bar. The emitter's tube produced a flat internal spiral path with a discharge of $4 \mathrm{~L} / \mathrm{h}$ under 1 bar operating pressure. Daily evaporation was measured using a class A-evaporation pan installed at the experimental site. A strip plot design with 4 replications was used. Nine soil conditioners were distributed in strips, with the drip irrigation treatments of 4 drip discharge levels $(2,4,6$ and $8 \mathrm{~L} / \mathrm{h}$ for 1 hour daily) in strips at right angles to the soil conditioner strips. Soil conditioner treatments were: poultry manure at $5 \mathrm{~kg} / \mathrm{hole}$; animal manure (cattle manure) at $5 \mathrm{~kg} /$ hole; $5 \mathrm{~kg}$ of perlite: soil mixture (1:3) added to each hole; $5 \mathrm{~kg}$ of peat moss: soil mixture (1:2) added to each hole; hot bitumen spread over the upper surface of the hole to prevent surface evaporation, according to [4]; bottomless plastic pots of $50 \times 50 \mathrm{~cm}$; bitumen mixed with soil used for filling the residual empty space after planting the seedlings; hot bitumen plastered on the walls of the hole before planting to prevent horizontal leakage (to prevent loss of water from filtration and evaporation); and untreated control. Table 1 shows details of both chicken and cattle manures.

In late July 2013 seed of leucaena (Leucaena leucocephala) was sown in plastic trays $(20 \times 50 \times 50 \mathrm{~cm})$ filled with a soil mixture in a greenhouse and irrigated daily. At 60 days old seedlings were transferred to plastic bags $(8 \times 12 \times 25 \mathrm{~cm})$ filled with the same soil mixture. These seedlings were irrigated with saline water containing $1.5 \mathrm{ds} / \mathrm{m}$ (irrigation water conductivity measured according to salt concentration). A permanent site was prepared by digging holes $(50 \mathrm{~cm}$ diameter $\mathrm{x} 50 \mathrm{~cm}$ deep), with inter-row and intra-row spacing of $3 \mathrm{~m}$, to which healthy seedlings were transferred during October 2013. The various soil-conditioning treatments were applied to the appropriate holes before seedlings were planted.

\section{Studied Characters}

Plants were harvested in both summer and autumn, and the following parameters were measured on each occasion: plant height; number of branches/plant; stem thickness (stem diameter)on an exactly ground surface; and fresh forage yield/ plant; dry forage yield/plant; dry forage yield per ha; and water use efficiency (WUE).

\section{Statistical Analysis}

All studied data were subjected to statistical analysis and method of means compared by the LSD test at $\mathrm{P}<0.05$ as described by [11]. A strip plot design in a RCBD of analysis of variance used by MSTAT-C computer package developed by [12].

\section{RESULTS}

\section{Soil Conditioners Treatments Effects}

The results in clearly revealed that stem height, branches number/plant, thickness of stems and dry forage yield/plant and ha as well as water use efficiency values in both summer and autumn cut significantly affected by soil conditioner treatments (Tables 2, 3, 4, 5 and 6) as combined analysis of both seasons. Applying manure as soil conditioners in sandy soil produced tallest shrubs, the highest values of a number of branches/plant, stem thickness and the highest dry matter forage yield/plant and ha and the highest values of water use efficiency at both summer and autumn cut. The corresponding of combined data was $97.4,103.4,8.9,10.9,5.46,6.38,4.579,4.843,3.021,3.165$ and 2.42, 2.66, respectively at both summer and autumn cut of combined seasons, respectively. Whereas, the shortest plants, the lowest branches number/plant, thick stem and the lowest dry forage yield/plant and ha and the lowest water use efficiency values at both summer and autumn cut, respectively obtained from the control treatments. The corresponding data were 91.0, $97.1,5.9,7.9,4.25,3.38,4.070,4.334,2.685,2.829,2.15$ and 2.10 both summer and autumn cut, respectively.

\section{Drip Irrigation Discharges Treatments Effects}

Pant height, number of branches/plant, stem diameter and dry matter forage yield/plant and per hectare as well as values of WUE at both summer and autumn cut significantly affected

Table 1: Chemical analysis of animal (cattle) and poultry manures

\begin{tabular}{|c|c|c|c|c|c|c|c|c|c|c|}
\hline Type & $\mathrm{Ec}(\mathrm{ds} / \mathrm{m})$ & $\mathrm{pH}$ & N (\%) & $\mathrm{P}(\%)$ & $\mathrm{K}(\%)$ & $\mathrm{Zn}(\mathrm{ppm})$ & $\mathrm{Mn}$ (ppm) & $\mathrm{Cu}(\mathrm{ppm})$ & Org. matter (\%) & Moisture (\%) \\
\hline Cattle manure & 4.3 & 9.5 & 2.8 & 0.79 & 1.96 & 78 & 49 & 62 & 19.8 & 16.6 \\
\hline Poultry manure & 5.7 & 7.5 & 4.5 & 1.86 & 2.88 & 39 & 41 & 67 & 18.2 & 21.8 \\
\hline
\end{tabular}


Table 2: Means of plant height in $\mathrm{cm}$ of Leucaena leucocephala as affected by the interaction between soil conditioners and drip irrigation discharges as their interaction of both summer and autumn cuts as combined analysis of 2014/2015 and 2015/2016 seasons

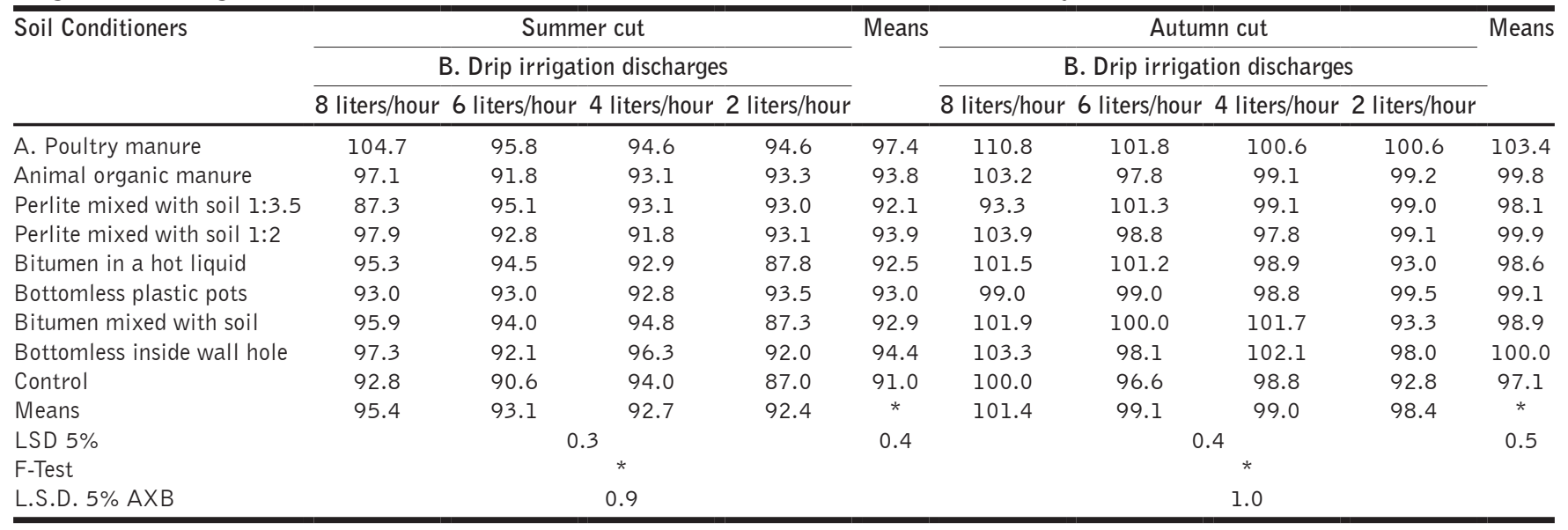

Table 3: Means of branches number per plant of Leucaena leucocephala as affected by the interaction between Soil Conditioners and Drip irrigation discharges of both summer and autumn cuts as combined analysis of 2014/2015 and 2015/2016 seasons

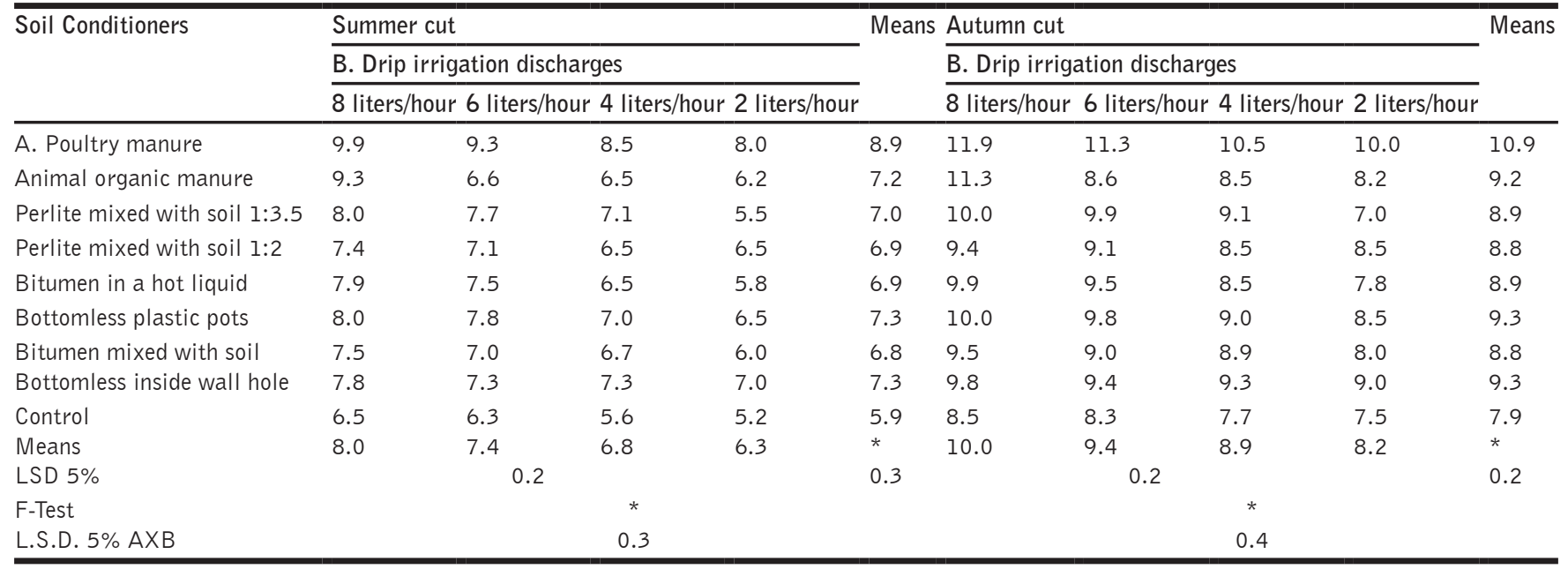

by drip irrigation discharges treatments as combined analysis of both seasons (Tables 2, 3, 4, 5 and 6). Swelling drip irrigation discharges from 2, 4, 6 to 8 litres/h significantly increased stem height, branches number per plant, thickness of stems and the highest dry matter forage yield/plant and per hectare as well as the highest values of water use efficiency at both summer and autumn cut during 2014 and 2015 seasons and combined analysis. The highest drip irrigation discharges (8 litres/hour) chronicled the tallest shrubs, the highest branches number/plant, thick stem and the highest dry matter forage yield/plant, and per hectare as well as the highest values of water use efficiency at both summer and autumn cut as combined analysis of both seasons. The corresponding date were 95.4, 101.4, 8.0, 10.0, 4.81, 5.25, $4.557,4.821,3.007,3.151,2.34$ and 2.75 , respectively. Whilst, the shortest plants, the lowest branches number, thin stem and the lowest dry matter forage yield/plant and per hectare and the lowest values of water use efficiency at both summer and autumn cut, respectively obtained from the lowest drip irrigation discharges i.e. 2 litres/hour. The corresponding data were, 92.4, 98.4, 6.3, 8.2, $4.81,5.25,4.077,4.348,2.697,2.827,2.26$ and 2.53 , respectively as combined analysis of both seasons. It cold noticed that below the organization of effective water irrigation, it is significant to know how produce per unit using few water application. Management using less water use enhancement in agronomic crops characters leads to water saving in dissimilar subdivisions. In addition, the deficit irrigation will save water and will not upset the yield [13].

\section{Interaction between Soil Conditioners and Drip Irrigation Treatments}

In view of the effect interaction between soil conditioners and drip irrigation discharges influenced stem thickness and water use efficiency values, the resulted accessible in Table (6) clearly revealed that, the interaction between soil conditioners and drip irrigation discharges insignificantly exaggerated at both summer and autumn cuts as a combined season of 2014/2015 and 2015/2016. Results presented in Tables (2, 3, 4, 5 and 6) detected that, the interaction between soil conditioner treatments and drip irrigation discharges influenced stem height, the number of branches/plant, and dry matter forage yield/plant and per hectare as well as water use efficiency at both summer and autumn cuts as combined analysis of both seasons. The results 
Table 4: Means of dry forage yield/plant (Kg/plant) of Leucaena leucocephala as affected by the interaction between Soil Conditioners and Drip irrigation discharges of both summer and autumn cuts as combined analysis of 2014/2015 and 2015/2016 seasons

\begin{tabular}{|c|c|c|c|c|c|c|c|c|c|c|}
\hline \multirow[t]{3}{*}{ Soil Conditioners } & \multicolumn{4}{|l|}{ Summer cut } & \multirow[t]{3}{*}{ Means } & \multicolumn{4}{|l|}{ Autumn cut } & \multirow[t]{3}{*}{ Means } \\
\hline & \multicolumn{4}{|c|}{ B. Drip irrigation discharges } & & \multicolumn{4}{|c|}{ B. Drip irrigation discharges } & \\
\hline & 8 liters/hour & 6 liters/hour & 4 liters/hour & 2 liters/hour & & 8 liters/hour & 6 liters/1 & our 4 liters/hour & 2 liters/hour & \\
\hline A. Poultry manure & 2.62 & 2.52 & 2.49 & 2.33 & 2.489 & 2.60 & 2.52 & 2.49 & 2.33 & 2.490 \\
\hline Animal organic manure & 2.44 & 2.40 & 2.33 & 2.24 & 2.354 & 2.44 & 2.44 & 2.32 & 2.24 & 2.355 \\
\hline Perlite mixed with soil $1: 3.5$ & 2.51 & 2.45 & 2.37 & 2.18 & 2.383 & 2.51 & 2.45 & 2.37 & 2.15 & 2.384 \\
\hline Perlite mixed with soil $1: 2$ & 2.44 & 2.36 & 2.33 & 2.30 & 2.373 & 2.43 & 2.36 & 2.36 & 2.33 & 2.374 \\
\hline Bitumen in a hot liquid & 2.49 & 2.42 & 2.33 & 2.16 & 2.359 & 2.49 & 2.43 & 2.33 & 2.33 & 2.359 \\
\hline Bottomless plastic pots & 2.49 & 2.41 & 2.37 & 2.31 & 2.403 & 2.50 & 2.42 & 2.36 & 2.31 & 2.403 \\
\hline Bitumen mixed with soil & 2.49 & 2.33 & 2.22 & 2.09 & 2.288 & 2.49 & 2.33 & 2.22 & 2.10 & 2.288 \\
\hline Bottomless inside wall hole & 2.45 & 2.38 & 2.35 & 2.28 & 2.371 & 2.45 & 2.38 & 2.35 & 2.28 & 2.271 \\
\hline Control & 2.35 & 2.27 & 2.16 & 2.05 & 2.213 & 2.35 & 2.27 & 2.16 & 2.05 & 2.213 \\
\hline Means & 2.475 & 2.393 & 2.327 & 2.215 & * & 2.473 & 2.400 & 2.328 & 2.235 & * \\
\hline LSD $5 \%$ & & & 05 & & 0.008 & & & 0.005 & & 0.008 \\
\hline F-Test & & & * & & & & & * & & \\
\hline L.S.D. $5 \% \mathrm{AXB}$ & & & 0.02 & & & & & 0.03 & & \\
\hline
\end{tabular}

Table 5: Means of dry matter forage yield/ha (t/ha) of Leucaena leucocephala as affected by the interaction between Soil Conditioners and Drip irrigation discharges of both summer and autumn cuts as combined analysis of 2014/2015 and 2015/2016 seasons

\begin{tabular}{|c|c|c|c|c|c|c|c|c|c|c|}
\hline \multirow[t]{3}{*}{ Soil conditioners } & \multicolumn{4}{|c|}{ Summer cut } & \multirow[t]{3}{*}{ Means } & \multicolumn{4}{|c|}{ Autumn cut } & \multirow[t]{3}{*}{ Means } \\
\hline & \multicolumn{4}{|c|}{ B. Drip irrigation discharges } & & \multicolumn{4}{|c|}{ B. Drip irrigation discharges } & \\
\hline & 8 liters/hour & 6 liters/hour & 4 liters/hour & 2 liters/hour & & 8 liters/hour & 6 liters/hour & 4 liters/hour & 2 liters/hour & \\
\hline A. Poultry manure & 3.156 & 3.064 & 3.028 & 2.834 & 3.021 & 3.300 & 3.208 & 3.172 & 2.978 & 3.3 \\
\hline Animal organic manure & 2.964 & 2.913 & 2.824 & 2.728 & 2.856 & 3.108 & 3.057 & 2.966 & 2.872 & 3.108 \\
\hline Perlite mixed with soil 1:3.5 & 3.055 & 2.976 & 2.882 & 2.652 & 2.892 & 3.199 & 3.12 & 3.105 & 2.796 & 3.199 \\
\hline Perlite mixed with soil 1:2 & 2.959 & 2.868 & 2.865 & 2.827 & 2.882 & 3.103 & 3.012 & 3.009 & 2.899 & 3.103 \\
\hline Bitumen in a hot liquid & 3.033 & 2.956 & 2.834 & 2.628 & 2.863 & 3.177 & 3.1 & 2.978 & 2.772 & 3.177 \\
\hline Bottomless plastic pots & 3.033 & 2.94 & 2.882 & 2.808 & 2.916 & 3.177 & 3.084 & 3.026 & 2.887 & 3.177 \\
\hline Bitumen mixed with soil & 3.031 & 2.832 & 2.697 & 2.546 & 2.776 & 3.177 & 2.976 & 2.844 & 2.692 & 3.177 \\
\hline Bottomless inside wall hole & 2.976 & 2.899 & 2.86 & 2.774 & 2.877 & 3.122 & 3.045 & 3.004 & 2.918 & 3.122 \\
\hline Control & 2.86 & 2.76 & 2.628 & 2.493 & 2.685 & 3.004 & 2.904 & 2.774 & 2.637 & 3.004 \\
\hline Means & 3.007 & 2.911 & 2.832 & 2.697 & * & 3.151 & 3.055 & 2.990 & 2.827 & * \\
\hline LSD $5 \%$ & \multicolumn{4}{|c|}{0.036} & 0.038 & \multicolumn{4}{|c|}{0.026} & 0.037 \\
\hline F-Test & \multicolumn{4}{|c|}{ * } & & \multicolumn{4}{|c|}{ * } & \\
\hline L.S.D. $5 \%$ AXB & \multicolumn{4}{|c|}{0.076} & & \multicolumn{5}{|c|}{0.079} \\
\hline
\end{tabular}

clearly detected that, the interaction between soil conditioner treatments and drip irrigation discharges significantly influenced stem height, the branches number per plant, and dry forage yield/plant and per hectare as well as water use efficiency at summer cut as combined analysis of both seasons. The tallest plants $(104.7 \mathrm{~cm})$ and the highest number of branches/plant (9.9 branches/plant) the highest dry matter forage yield/plant (3.62 kg/plant), and the highest dry matter forage yield/ha (3.156 $\mathrm{t} / \mathrm{ha}$ ) obtained from applying poultry manure as soil conditioners and irrigation discharges at 8 litres $/ \mathrm{h}$ at summer cut as combined analysis of both seasons. The results indicated that the shortest plants $(87.0$ and $92.8 \mathrm{~cm})$, the lowest number of branches/ plant ( 5.2 and 7.5 branches/plant), the lowest dry matter forage (2.05 kg/plant, and the lowest dry matter forage yield/ha (2.637 $\mathrm{t} / \mathrm{ha}$ ) were obtained from without conditioner treatments and drip irrigation discharges at 2 litres/h at autumn cut. The results presented in Tables $(2,3,5$ and 6$)$ clearly detected that the interaction between soil conditioner treatments and drip irrigation discharges significantly affected stem height, the number of branches/plant, dry matter forage yield/plant and total dry matter forage yield/ha at autumn cut as combined analysis of both seasons. The tallest plants $(110.8 \mathrm{~cm})$, the highest number of branches/plant (11.9 branches/plant), the highest dry forage yield/plant (2.60 kg/plant), and the highest dry forage yield/ha (3.300 t/ha) were obtained from applying poultry manure as soil conditioners and irrigation discharges at 8 litres/h at both summer and autumn cuts. The results showed that the shortest plants $(87.0 \mathrm{~cm})$, the lowest number of branches/plant $(5.2$ and 7.5 branches/plant), the lowest dry forage $(2.05 \mathrm{~kg} /$ plant $)$, and the lowest fresh forage yield/ha $(2.493 \mathrm{t} / \mathrm{ha})$ were obtained from without conditioner treatments and drip irrigation discharges at 2 litres/h at summer cut as combined analysis of both seasons.

\section{DISCUSSIONS}

There is a need to increase productivity of grazing land without humiliating the natural resources to increases to ask for meat and protein sources. This can accomplished by 
Table 6: Means of stem thickness and values of water use efficiency of Leucaena leucocephala as affecting by Soil Conditioners and Drip irrigation discharges of both $\mathrm{S}$ and $\mathrm{A}$ cut during 2014/2015 and 2015/2016 seasons and combined of both seasons

\begin{tabular}{lcccc}
\hline Treatments & \multicolumn{2}{c}{$\begin{array}{c}\text { Stem } \\
\text { thickness }(\mathrm{mm})\end{array}$} & \multicolumn{2}{c}{$\begin{array}{c}\text { Water use } \\
\text { efficiency }\end{array}$} \\
\cline { 2 - 5 } & S cut & A cut & S cut & A cut \\
\hline A. Soil Conditioner: & & & & \\
Poultry manure & 5.9 & 6.4 & 2.42 & 2.66 \\
Animal organic manure & 5.2 & 5.6 & 2.29 & 2.60 \\
Perlite mixed with soil 1:3.5 & 5.2 & 5.7 & 2.33 & 2.69 \\
Perlite mixed with soil 1:2 & 4.8 & 5.2 & 2.31 & 2.70 \\
Bitumen in a hot liquid & 4.3 & 4.8 & 2.29 & 2.74 \\
Bottomless plastic pots & 4.7 & 5.2 & 2.34 & 2.63 \\
Bitumen mixed with soil & 4.8 & 5.3 & 2.32 & 2.63 \\
Bottomless inside wall hole & 4.1 & 4.6 & 2.22 & 2.60 \\
Control & 3.6 & 4.0 & 2.15 & 2.55 \\
F-Test & $*$ & $*$ & $*$ & $*$ \\
LSD 5\% & 0.2 & 0.1 & 0.02 & 0.04 \\
B. Drip irrigation discharges: & & & & \\
8 liters/hour & 5.2 & 5.6 & 2.34 & 2.75 \\
6 liters/hour & 4.7 & 5.3 & 2.29 & 2.69 \\
4 liters/hour & 4.6 & 5.2 & 2.26 & 2.66 \\
2 liters/hour & 4.5 & 5.0 & 2.13 & 2.53 \\
F-Test & $*$ & $*$ & $*$ & $*$ \\
L.S.D. 5\% & 0.1 & 0.1 & 0.03 & 0.03 \\
Interaction A x B F-Test & $\mathrm{N} . \mathrm{S}$. & $\mathrm{N} . \mathrm{S}$. & $\mathrm{N} . \mathrm{S}$. & $\mathrm{N} . \mathrm{S}$. \\
\hline & & & &
\end{tabular}

cumulative production of educated pastures or enlightening rangeland plants [14] by producing higher nutritional value of foliage than that of forage grasses. Soil conditioners and drip discharge treatments markedly influenced on various growth characteristics. Both poultry and animal manure as well as 6 liters'/hour treatments produced greater average, while small averages obtained from control and bitumen inside the wall hole. Leaves contained $63 \%$ of its fresh weight as moisture, which is instrumental in providing grazing fowl with most of their water requirements. Moreover, woody stems constituted the majority of Leucaena yield. This considered a valuable source of fuel and hutch timber [4]. A similar conclusion were reported by $[15,16,17]$. Manufactured erosion control substances can reduce the runoff or evaporation. But if the soil conditioners only is applied, the efficiency will be low $[18,19]$.

Determination of water use efficiency habitually considered an important determinant of yield under water defect and drought resistance. Water use efficiency used to suggest construction of rain-fed plants per unit water used [20]. In order to increase the production and reducing the water consumption in agriculture increased the efficiency of using water. Management of effective water irrigation in arid and semi-arid regions, could increase crop production and enhance water resources [8]. It is fact; increasing the water application rate did not increase the water use efficiency. It could state that irrigation rate at 0.50 actual evapotranspiration maybe utilized for Leucaena irrigation. The drip at deficit water will increase water use efficiency [9].

Highest fresh forage and dry matter yield/ha were obtained from applying poultry manure as soil conditioners and irrigation discharges at 8 litres/hour at summer cut as a combined season.
Many research such as [4] showed that soil conditioners and drip discharge treatments markedly influenced on various growth characteristics. Using poultry and animal manure with irrigation 6 liter/h dishrag produced the preponderant averages, while small averages obtained from control and bitumen inside the wall hole. Leaves contained 63\% moisture of its fresh weight, which is instrumental in providing grazing fowl with most of their water requirements. Moreover, woody stems constituted of Leucaena yield. This considered a valuable source of fuel and hutch timber. A similar conclusion were reported by $[8,9,16,17,18]$.

\section{CONCLUSION}

It could have concluded that applying poultry manure as soil conditioners in sandy soil and increasing drip irrigation discharges to eight litters/hour significantly increased forage dry matter production and water use efficiency of Leucaena leucocephala under North Delta region, Egypt.

\section{ACKNOWLEDGMENTS}

Project team would like to thank Mansoura University Research Unit due to fund this investigation through funding this work. In addition, many thanks to college staff for assistance during field experiments and experimental analysis.

\section{REFERENCES}

1. Winrock. International Wood Production and Use. Nitrogen Fixing Tree Association, P. O. Box 680, Waimanalo, Hawaii, 1985, 96795, USA.

2. Casanova-Lugo F, Ramírez-Avilés L, Solorio-Sánchez FJ. Effect of pruning interval on foliage and root bio-mass in forage tree species in monoculture and in association. Tropical and Subtropical Agroecosystems 2010 12:33-41.

3. Murgueitio E, Calle Z, Uribe F, Calle A, Solorio B. Native trees and shrubs for the productive rehabilitation of tropical cattle ranching lands. Forest Ecology and Management 2011, 261: 1654-1663.

4. Abou-deya I.B, Kandil AA. Soil conditioners and irrigation regime influences on Leucaena under severe barrenness. Desert Institute Bulletin, Egypt 1996 46: 197-213.

5. Thrall PH, Laine AL, Broadhurst LM, Bagnall DJ, Brockwell J. Symbiotic Effectiveness of Rhizobial Mutualists Varies in Interactions with Native Australian Legume Genera. PLOS ONE, 2011 8. e23545.

6. Costa NDL, Paulino VT, Magalhaes JA. Effects of cutting regimes on forage yield and chemical composition of Leucaena leucocephala. PUBVET Londrina, 20148 (20): 269 Art. 1791.

7. Fernando C, Francisco JS, Luis R, José AC, Juan CK. Forage yield and quality of Leucaena leucocephala and Guazuma ulmifolia in tropical silvopastoral systems. Tropical Grasslands, 2014 2: 24-26.

8. Elasu BK; Steyn JM; Soundy P. 2009. Physio morphological response of rose-scented geranium (Pelargonium spp.) to irrigation frequency. Agricultural Water Management 96: 1-16.

9. Al-Mefleh NK, Tadros MJ. Influence of water quantity on the yield, water use efficiency, and plant water relations of Leucaena leucocephala in arid and semi-arid environment using drip irrigation system. African Journal of Agricultural Research, 2010 5: 1917-1924.

10. Lazaridou M, Karatassiou M, Kostopoulou P. Cutting and water deficit effect on water use efficiency of forage species. Grazing and Ecosystem Services. Proceedings of $9^{\text {th }}$ European Dry Grassland Meeting (EDGM) 19-23 May 2012, Prespa, Greece.

11. Gomez KA, Gomez AA. Statistical Procedures in Agricultural Research. John Wiley and Sons, 1991 New York.

12. Russell DF. MSTAT-C computer based data analysis software. Crop and Soil Science Department, Michigan State University, 1986 USA. 
13. Spreer W, Ongprasert S, Hegele M, Wunshe JN, Muller J. Yield and fruit development in mongo (Mangifera india L.V. Chok) under different irrigation regimes. Agricultural Water Management, 2008 96: 1-14.

14. Ku Vera JC, Ramírez Avilés $L$, Jiménez Ferrer G, Alayón JA, Ramírez Cancino L. Árboles y arbustos para la producción animal en el trópico mexicano". En: Agroforestería para la Producción Animal en América Latina. FAO. Roma Italia, 1999 Pp. 231-250.

15. Wong MTF; Swift RS 2003. Role of organic matter in alleviating soil acidity. In: Rengel, Zdenko (Ed.), Handbook of Soil Acidity. Marcel Dekker, Inc., NY, USA, pp. 337-358.

16. Ortiz EME; Hue NV. 2008. Temporal changes of selected chemical properties in three manure Amended soils of Hawaii. Bioresource Technology 99:8649-8654.
17. Sary GA, Roshdy A, Zaghloul AK, Ghonem MAM. Effect of some soi chemical stabilizers on growth of leucaena leucocephala and Acacia salign. Annals of Agricultural Science, Moshtohor, 2010 48: 49-61.

18. Akbarzadeh A, Taghizadeh Mehrjardi R, Refahi HG, Rouhipour H, Gorji M. Application of soil conditioners and man-made erosion control materials to reduce erosion risk on sloping lands. African Journal Plant Science, 2009 3: 074-084.

19. Pereyra G, Henrik H, Michalzik B, Ziegler W, Trumbore S. Influence of Rhizobia Inoculation on Biomass Gain and Tissue Nitrogen Content of Leucaena leucocephala Seedlings under Drought. Forests,2015 6: 3687- 3703

20. Greenwood KL, Lawson AR, Kelly KB. The water balance of irrigated forages in northern Victoria, Australia. Agricultural Water Management, 2009 96: 847-858. 